\title{
Effect of Cloud Based Educational Applications in E- learning: Evidence from Jordan
}

\author{
https://doi.org/10.3991/ijim.v11i4.6378 \\ Bader Methqal AlFawwaz \\ Al al-Bayt University, Mafraq, Jordan \\ bm_alfawwaz@aabu.edu.jo
}

\begin{abstract}
Cloud computing is a new paradigm in E-learning environment. It offers a wide range of facilities to students and teachers, especially in the universities to ease out their problem in terms of documents sharing, course material distribution and handling, desktop sharing by the teachers to teach their students, and in terms of Voice Over IP (VOIP) and video conferencing for the smooth communication with each other. In this modern world, e-learning can be improved by utilizing these and similar to these cloud based applications. The objective of this paper is to find out how e-learning can be more effective by utilizing the cloud based educational applications and what is the role of these applications in increasing the efficiency of electronic learning in the universities of Jordan. The study is evidence from Jordan and data was collected from teachers and students of five major universities of Jordan through an online survey tool. Results shows that there is a positive highly significant relation between clouds based educational applications such as Google App Microsoft, Amazon, IBM, Google Drive, Team viewer, Skype, Net meeting, WebEx with the electronic learning in Jordan Universities. Findings are beneficial for those universities and educational institute which are not using or offering these cloud based educational applications, so they will come to know how these applications can play a vital role in e-learning educations.
\end{abstract}

Keywords-Cloud Computing, E-Learning, File Sharing, Desktop Sharing, Voice Over IP (VOIP).

\section{Introduction}

The tendency of getting electronic learning education is vital these days. Due to time constraints, lack of financial resources, lack of transportation, and similar factors the distance learning through electronic ways is on peak these days. Not only students, but also professionals who are working in different companies, and who wants to improve their education but do not have enough time to attend regular classes, they are also the potential customers of electronic education. Due to this tendency towards usage of e-learning technology, the need of certain solutions to electronic education problems is raised. In order to increase the efficiency of electronic learning, there is a need to develop faster, reliable, easy to use, easy to connect services and web based 
applications by which a customer cannot only communicate with each other but also a customer can have full access to all learning material. E-learning is the solution of distance education [1]. Need of recon-structuring teaching education arise when students face difficulty in reaching out the campuses and prefer to earn a degree by sitting on distant locations [2]. If we do the comparison of traditional learning and elearning, we came to know that most of the students and even teachers preferred elearning [3].

Several web services introduced by different universities and educational institutes, in which a faculty member can teach and educate his / her students sitting in one corner of the world. In this fast paced learning environment, one cannot only rely on traditional education methods, but management of institutes and learning centers need to decide to what extent they can enhance their educational channel around the globe to increase and even maintain the conducive learning environment. The matter of fact that if these learning center will not decide now, that they must adopt advance ways of education then others could easily obsolete them. The traditional learning system is now becoming increasingly complex and tendency to learn through distant learning in virtual environment is increasing [4]. One of the critical key success factors of elearning in developing countries is cost of transportation. Students must pay extra cost to reach out the learning facility to gain education [5].

So the point of discussion here is that there is a strong need of developing advance electronic learning tools which are fully capable of faster and reliable documents sharing, course material distribution and handling, desktop sharing by the teachers to teach their students, and in terms of Voice Over IP (VOIP) for the smooth communication with each other. In order to fulfill this need and to face these problems electronically, the need of developing high quality cloud based educational applications become increasing.

Cloud computing is an advanced term in computing. Cloud is related to something which is designed to ease out and even eliminate the cost of infrastructure, data handling, storage, large computer screens large networks and similar stuff like that. It is an imperative service introduced by the technology experts to meet the obligation of demanding customers.

In this article, we study how cloud computing can use electronic learning education in five major Universities of Jordan which are University of Jordan, Yarmouk University, Hashemite University, Al-Hussain Bin Talal University and Mutah University. We debate the cloud computing instructive situation and discover what the effects of these cloud based applications are not only in terms of cost but also in terms of portability, safety, competence, flexibility, and reliability. Furthermore, how institutions and universities might take benefit of clouds.

This article is divided into sections, the next section includes purpose of the study and the research question, the second section includes cloud computing education in Jordan, the third section includes theoretical framework, while the fourth section includes methodology, the fifth section includes results and discussions and finally the last section includes conclusion and recommendations. 


\section{Purpose of the Study}

The aim of the study is to observe the effect of cloud based educational applications in e-learning education in Universities of Jordan.

\section{$3 \quad$ Research Question}

What is the role of cloud based educational applications in e-learning education in the context of Jordanian Universities and learning institutes?

\subsection{Sub Questions}

-What role cloud based educational applications for file and documents sharing can play in e-learning education system of Jordan?

- What role cloud based educational applications for desktop sharing can play in elearning education system of Jordan?

- What role cloud based educational applications for Voice Over IP (VOIP) \& video conferencing can play in e-learning education system of Jordan?

E-learning defined as a communication between computers and teachers and their respective students. It is a web based process use by means of online tools and resources [6]. Electronic learning can be defined as all methods of electronically maintained education and coaching. It interconnects various arenas of practice and thought for instance education and training, technology, knowledge and learning. Electronic education can be characterized into two core categories, asynchronous and synchronous. With asynchronous education, a pupil can join in the knowledge accomplishments at the most appropriate time for him or her but this also shows that the teacher will not be presented for instant answers. With synchronous electronic education, pupils can join the course that encounters online with the instructor through running video and audio at a prearranged time. This course is already scheduled and students just have to be online at that time [7].

Cloud computing is a type of computing where strongly accessible and online resources are offered as a service over the Web. According to [8], resources utilization is a necessary requirement in the environment of a cloud computing. [9] argues that cloud computing is one of the latest developments in the world of Information Technology. Cloud Computing shared information resources within a specific network. In the environment of cloud computing, scheduling of tasks on many virtual machines is very important point. This is done for two main reasons; minimize makespan and increase system utilization [10]. Moreover, planned scheduling is needed for both cloud providers and cloud users [11]. The cloud permits structures to strongly offer the computing sources their user's need, energy consumption, dropping expenses and refining on their scalability. The usage of cloud computing in education is vital. Numbers of usage of cloud based educational applications such as Google Drive, Drop Box and YouTube Education Channels are increasing. 


\section{Cloud Computing Education in Jordan}

Jordanian residents are young, with $70 \%$ below the age of 30 and a $97 \%$ literacy rate [12]. With substantial finances required in higher education and the rising demand for Information Technology (IT) facilities, learning centers in Jordan are fronting problems in offering essential Information Technology (IT) provision for institutional, research and development actions.

Results of a study by [13] recommend that when seeing a cloud approach for education in distinctive learning centers in Jordan, a very significant fact that should be engaged into attention is the data security problem, superior consideration must be given to the complex data from the learning centers (for instance, students' scholastic records, research results, employees' accounts). The leading step that might be considered concerning data is to preserve the complex data inside the university data centers (Computer Labs) and outsource the other data with the hazard of attaining some dormancy for numerous users and applications.

Another study conducted in Jordan discuss and lists main barriers and encounters that might face instructors at the public learning centers in Jordan in utilizing electronic learning systems using cloud based educational tools in their teaching. [14] found that electronic learning systems using cloud based educational tools permit faculty members to simply generate and distribute their electronic lectures and electronic contents. Additionally, electronic course resources which uploaded by consuming such web cloud based educational tools could be operated by any widespread web browser system.

\subsection{File/Documents Sharing}

One of the important cloud based education application is file / documents sharing. Although there are several other documents sharing web services and most of them are even free to use such as Drop Box. However, the renowned and most common application used is Google Drive [15]. This application is use for file and documents sharing among different users. Results of a research shows that most of the document sharing services are not only valuable in terms of low or zero infrastructure cost, but also an efficient way performing as a facility of knowledge bridge between the students and faculty members [16]. This cloud based web application is widely using for the e-learning purposes.

\subsection{Desktop Sharing}

Desktop sharing is a public name for products and technologies that permit remote collaboration and remote access on an individual's computer desktop by a graphical terminal emulator [17]. Although there are several other documents sharing web services and most of them are even free to use such as Team Viewer. However, the renowned and most common application used is Skype. In desktop sharing process, users cannot only share their desktop screens but it is also possible that one user can access and get control to the other user screen. By doing this one user can easily per- 
form any activity such as configuration of a complex software to the other user computer [18]. This cloud based web application is in widely used by the faculty member and students for the e-learning purposes.

\subsection{VOIP/Video Conference}

"Voice Over IP (VoIP) is a methodology and group of technologies for the delivery of voice communications and multimedia sessions over Internet Protocol networks" [19]. Findings of a study indicates that web based voice calling over IP phones and video conferencing tools emphasizing on NetMeeting as the most efficient learning tool are getting better results than those who are using traditional ways of learning [20].

\section{Theoretical Framework}

The Theoretical Framework of "Effect of Cloud Based Educational Applications in E-learning Education: Evidence from Jordan"

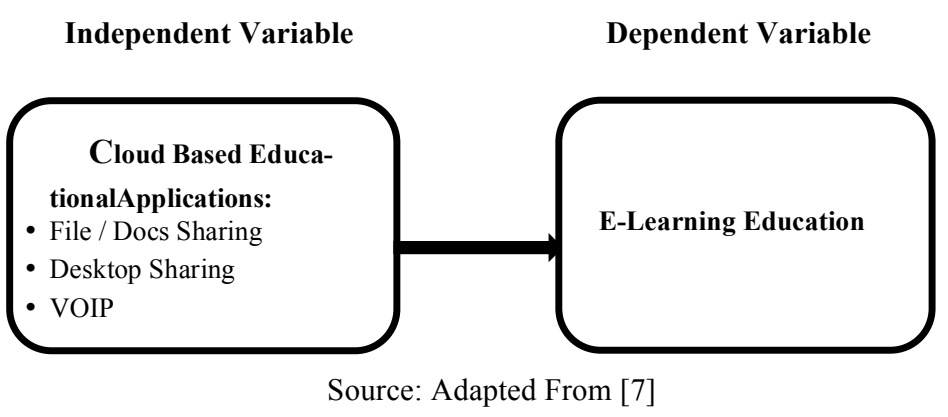

\section{$6 \quad$ Methodology}

\subsection{Study Design}

In this investigation, a descriptive cross sectional study design will be used to answer the main research question. Aim of the study is to find out effect of cloud based educational applications on e-learning in Jordan. Moreover, the study also aims to identify the role of file and documents sharing applications, desktop sharing applications and Voice Over IP applications on e-learning in Jordan. In order to observe practices at clinical setting, the data was collected by using online survey tools, which was spread in different universities of Jordan among enrolled faculty members and students. Therefore, this study design is well-suited to answer the research question and achieve the proposed study objectives. 


\subsection{Study Population and Setting}

All faculty members and students, especially those who are in distance learning and e-learning programs has been observed for their practices of electronic learning. The setting of the study is in Jordan. The study was conducted in University of Jordan, Yarmouk University, Hashemite University, Al-Hussain Bin Talal University and Mutah University. The faculty members and students varies in all disciplines of education.

\subsection{Inclusion Criteria}

The inclusion criteria of the study is faculty members, students, instructors, and other education members such as lab assistants and librarians who are part of these universities, enrolled as a full time members, doing morning and evening shift duties and those who are willing to participate in the study including: academics staff.

\subsection{Exclusion Criteria}

Those are not included who are not relevant with the educational systems and those are also excluded who are former students or Alumni's or former teachers.

\subsection{Sampling and Data Collection}

The samples were selected by use of random sampling method. The questionnaires were distributed among the faculty members and students of University of Jordan, Yarmouk University, Hashemite University, Al-Hussain Bin Talal University and Mutah University by using Email and Monkey Survey tool. This was all held on Internet so it was comparatively easy to organize, record and analyze the data. Data was collected from faculty members and students of above mentioned universities. Out of 320 distributed questionnaires, 280 were received back which were properly and fully filled. The response rate is $87.5 \%$ which is sufficient to carry out this research.

\subsection{Questionnaire}

All items were on a five point Likert scale with Strongly Disagree on 01 and strongly agree is on 05 . Other options were Agree, Neutral and Disagree. The questionnaire was adapted from [7] and each question in properly entered in SPSS 20 and then reliability test was conducted. Table (1) shows the Cronbach alpha for each dimension of independent variable. Similarly, Table (2) shows the overall case processing summary generated by the SPSS 20 . 
Table 1. Reliability Test

\begin{tabular}{|l|c|c}
\hline \multicolumn{1}{|c|}{ Variables } & Cronbach Alpha & N of Items \\
\hline File / Docs Sharing & 0.86 & 04 \\
\hline Desktop Sharing & 0.89 & 04 \\
\hline Voice Over IP / Video Conferencing & 0.74 & 04 \\
\hline
\end{tabular}

Table 2. Case Processing Summary

\begin{tabular}{|c|c|c|c|}
\hline & & $N$ & $\%$ \\
\hline \multirow{3}{*}{ Cases } & Valid & 280 & 87.5 \\
\hline & Excluded $^{\mathrm{a}}$ & 40 & 12.5 \\
\hline & Total & 320 & 100.0 \\
\hline
\end{tabular}

a. Listwise deletion based on all variables in the procedure.

\subsection{Demographic Statistics}

When applied demographic test to the demographic questions by using the SPSS 20, results are received. According to the Table (3) it was found that out of total 320 respondents 198 are Male and 122 are Female. This shows that $61.2 \%$ are male and $38.1 \%$ are females.

Table 3. Gender

\begin{tabular}{|ll|c|c|c|c}
\hline & & Frequency & Percent & Valid Percent & Cumulative Percent \\
\hline Valid & Male & 198 & 61.2 & 58.8 & 87.00 \\
& Female & 82 & 38.1 & 28.2 & 100.0 \\
& Total & 319 & 98.3 & 100.0 & \\
Missing & System & 1 & 1.7 & & \\
Total & & 320 & 100.0 & & \\
& & & & & \\
\hline
\end{tabular}

Most of the respondents which filled the questionnaire are graduates. A common phenomenon has been observed while collecting the data is this that most of the respondents are very well qualified or with having certifications.

\section{$7 \quad$ Results and Discussions}

In statistics, "regression analysis is a statistical process for estimating the relationships among variables. It includes many techniques for modeling and analyzing several variables, when the focus is on the relationship between a dependent variable and one or more independent variables" [21]. 


\subsection{Regression Results File / document sharing \& E-learning Education in Jordan}

This regression analysis is carried out using SPSS 20 and results are presented in Table (4). Standardized coefficients beta value and T-stats are also given in the last columns.

Table 4. File/Document Sharing \& E-Learning Education

\begin{tabular}{|c|c|c|c|c|c|c|}
\hline & \multicolumn{2}{|c|}{$\begin{array}{l}\text { Unstandardized } \\
\text { Coefficients }\end{array}$} & \multirow{2}{*}{$\begin{array}{c}\begin{array}{c}\text { Standardized } \\
\text { Coefficients }\end{array} \\
\text { Beta }\end{array}$} & \multirow[b]{2}{*}{$\mathbf{T}$} & & \multirow[b]{2}{*}{ Sig } \\
\hline & B & $\begin{array}{r}\text { Std } \\
\text {. Error } \\
\end{array}$ & & & & \\
\hline (Constant) & .994 & $6^{.57}$ & & $6^{2.72}$ & 7 & .04 \\
\hline File/docs sharing e-learning & .027 & $2^{.11}$ & .523 & $9^{3.23}$ & 1 & .00 \\
\hline
\end{tabular}

a. Dependent Variable: E-learning Education

As per Table (4), the dependent variable is E-learning Education, where as independent variable is File / document sharing. According to the results in Table (4) the beta value for File/docs sharing e-learning is 0.523 , whereas t-value is 3.239 which show significant relationship between the two variables. These results are also consistent with the results of a study which was conducted by [22] on using the Facebook group for file sharing / document sharing as a learning management system. They also found that it enhances the e-learning education.

Table 5. Model Summary

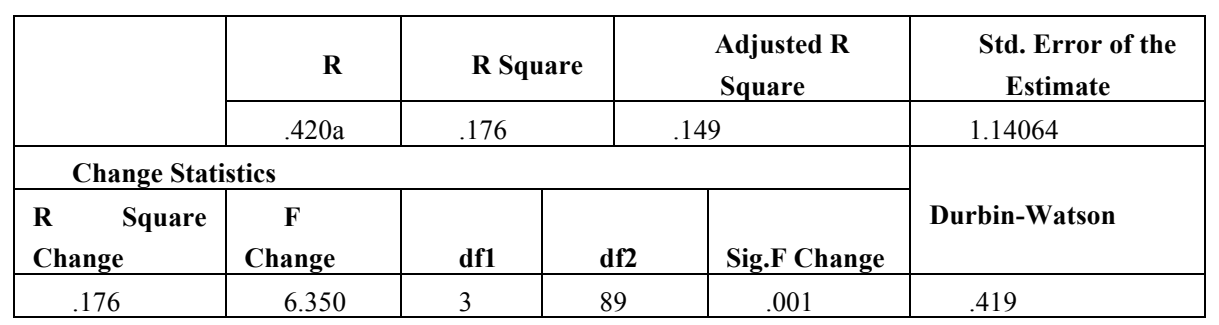

a. Predictors: (Constant), Desktop Sharing, Voice Over IP (VOIP)

b. Dependent Variable: E-learning Education

Table (5) illustrates the R square but also Adjusted $\mathrm{R}$ square is given which is more reliable for this case. As per Table (5), R-Square is 0.176 and adjusted R-square is 0.149 . Also the Durbin Watson value is 0.419 which shows that there might be autocorrelation problem in the data which is employed to carry out statistical analysis. 


\subsection{Regression Results Desktop Sharing \& E-learning Education in Jordan}

Regression Analysis for Desktop Sharing \& E-learning Education is done and results are in Table (6). Standardized coefficients beta value and T-stats are also given in the last columns.

Table 6. Desktop Sharing \& E-Learning Education

\begin{tabular}{|c|c|c|c|c|c|}
\hline & \multicolumn{2}{|c|}{$\begin{array}{l}\text { Unstandardized } \\
\text { Coefficients }\end{array}$} & \multirow{2}{*}{$\begin{array}{c}\text { Standardized } \\
\text { Coefficients } \\
\text { Beta } \\
\end{array}$} & \multirow[b]{2}{*}{$\mathbf{T}$} & \multirow[b]{2}{*}{ Sig } \\
\hline & B & $\begin{array}{r}\text { Std. } \\
\text { Error }\end{array}$ & & & \\
\hline (Constant) & -1.750 & .403 & & 4.342 & .039 \\
\hline Desktop sharing and E-learning & .626 & .085 & 2.631 & 7.377 & .031 \\
\hline
\end{tabular}

a. Dependent Variable: E-learning education

As per Table (6), the dependent variable is E-learning Education, where as independent variable is Desktop Sharing. According to the results the beta value is 2.631, whereas t-value is 7.377 which show highly significant relationship between the two variables. The results are also consistent with another study which was previously done by [23] about Computer Supported Collaborative Learning desktop sharing applications and their impact on virtual learning system. They found that such applications plays vital role in spreading e-learning education.

Table 7. Model Summary

\begin{tabular}{|c|c|c|c|c|c|}
\hline & $\mathbf{R}$ & R Square & \multicolumn{2}{|c|}{ Adjusted R Square } & $\begin{array}{l}\text { Std. Error of the } \\
\text { Estimate }\end{array}$ \\
\hline & $.710 \mathrm{a}$ & 3.505 & \multicolumn{2}{|c|}{3.488} & .86647 \\
\hline \multicolumn{5}{|c|}{ Change Statistics } & \multirow[b]{2}{*}{ Durbin-Watson } \\
\hline $\begin{array}{cr}\text { R } & \text { Square } \\
\text { Change } & \\
\end{array}$ & F Change & df1 & df 2 & $\begin{array}{l}\text { Sig.F } \\
\text { Change }\end{array}$ & \\
\hline .505 & 30.228 & 3 & 89 & .000 & 2.509 \\
\hline
\end{tabular}

a. Predictors: (Constant), File/docs sharing, VOIP

b. Dependent Variable: E-learning Education

Table (7) illustrates the R square but Adjusted R square is given which is more reliable for this case. R-Square is 3.505 and adjusted R-square is 3.488. Also, the Durbin Watson value is 2.509 which shows that there is no autocorrelation problem in the data which is employed to carry out statistical analysis. 


\subsection{Regression Results Voice Over IP, Video Conferencing \& E-learning Education in Jordan}

Regression Analysis for Voice Over IP, Video Conferencing \& E-learning Education is done and results are in Table (8). Standardized coefficients beta value and Tstats are also given in the last columns.

Table 8. Voice Over IP, Video Conferencing \& E-Learning Education

\begin{tabular}{|c|c|c|c|c|c|}
\hline & \multicolumn{2}{|c|}{$\begin{array}{l}\text { Unstandardized } \\
\text { Coefficients }\end{array}$} & \multirow{2}{*}{$\begin{array}{c}\text { Standardized } \\
\text { Coefficients } \\
\text { Beta } \\
\end{array}$} & \multirow[b]{2}{*}{$\mathbf{T}$} & \multirow[b]{2}{*}{ Sig } \\
\hline & B & $\begin{array}{r}\text { Std. } \\
\text { Error }\end{array}$ & & & \\
\hline (Constant) & -2.750 & .303 & & 5.342 & .029 \\
\hline $\begin{array}{l}\text { Voice Over IP, Video Confer- } \\
\text { encing \& E-Learning }\end{array}$ & .626 & .085 & 2.432 & 8.476 & .031 \\
\hline
\end{tabular}

a. Dependent Variable: E-learning Education

As per Table (8), the dependent variable is E-learning Education, where as independent variable is Voice Over IP, Video Conferencing. According to the results the beta value is 2.432 , whereas t-value is 8.476 which show highly significant relationship between the two variables.

Table 9. Model Summary

\begin{tabular}{|c|c|c|c|c|c|}
\hline & $\mathbf{R}$ & R Square & \multicolumn{2}{|c|}{ Adjusted R Square } & $\begin{array}{l}\text { Std. Error of the } \\
\text { Estimate }\end{array}$ \\
\hline & $.810 \mathrm{a}$ & 4.505 & \multicolumn{2}{|c|}{4.488} & .76647 \\
\hline \multicolumn{5}{|c|}{ Change Statistics } & \multirow[b]{2}{*}{ Durbin-Watson } \\
\hline $\begin{array}{cr}\text { R } & \text { Square } \\
\text { Change } & \\
\end{array}$ & F Change & df1 & df 2 & Sig.F Change & \\
\hline .605 & 29.228 & 4 & 79 & .000 & 3.677 \\
\hline
\end{tabular}

a. Predictors: (Constant), File/docs sharing, VOIP

b. Dependent Variable: E-Learning Education

Table (9) illustrates the R square but Adjusted R square is given which is more reliable for this case. R-Square is 4.505 and adjusted R-square is 4.488. Also, the Durbin Watson value is 3.677 which shows that there is no autocorrelation problem in the data which is employed to carry out statistical analysis. The results are consistent with a study conducted by [24] regarding Experiences Obtained with Integration of Student Sharing Systems for iPod Touch and iPhone into e-Learning Environments. Findings of the study indicates that there are several apps available in iPhone and in IPod through which students can share their screens and other materials in so to get ease out and eliminate their e-learning obstacles. 


\section{Conclusion \& Recommendations}

The aim of this research stream was to empirically determine that how e-learning can be more effective by utilizing the cloud based educational applications and what is the role of these applications in increasing the efficiency of learning among for the university students. The questionnaire was adapted from [7] and each question in properly entered in SPSS 20 and then reliability test was conducted. The samples were selected by use of random sampling method. The questionnaires were distributed among the faculty members and students of University of Jordan, Yarmouk University, Hashemite University, Al-Hussain Bin Talal University and Mutah University by using Email and Monkey Survey tool.

The results show that positive highly significant relation between documents sharing and file sharing with e-learning education, similarly positive highly significant relationship between desktop sharing and e-learning education, and also positive highly significant relationship between Voice Over IP and video conferencing with elearning education in the universities of Jordan. The findings are consistent with the previous published literature and findings are beneficial for the universities, colleges and even policy makers in Jordan so they can implement more cloud based educational applications in order to enhance the effectiveness of electronic learning around the country.

This article concludes that educational cloud computing is a novel tendency for elearning in Jordan and demonstrates how campuses and universities can take benefit of the cloud not merely in terms of budget but similarly competence, safety, consistency and transferability. Numerous instances of cloud computing in education such as Google App Microsoft, Amazon, IBM, Google Drive, Team viewer, Skype, Net meeting, WebEx and some of the cloud based applications use to do file / documents sharing, desktop sharing and Voice Over IP and video conferencing. The forthcoming encounters to this novel tendency comprising difficulties and dangers have been also deliberated. We trust that cloud computing unlocks a novel era in teaching and e-learning as it delivers a springy, cost effective and well-organized structure that campuses and learning centers can organize to permit their faculty and students complete their work faster and better than ever.

\section{$9 \quad$ References}

[1] Moore, M. G., \& Kearsley, G. (2011). Distance education: A systems view of online learning. Cengage Learning

[2] Elliott, J. (2011). Reconstructing teacher education (Vol. 221). Routledge.

[3] Arnove, R. F., Torres, C. A., \& Franz, S. (Eds.). (2012). Comparative education: The dialectic of the global and the local. Rowman \& Littlefield Publishers .

[4] Van Merriënboer, J. J., \& Kirschner, P. A. (2012). Ten steps to complex learning: A systematic approach to four-component instructional design. Routledge.

[5] Bhuasiri, W., Xaymoungkhoun, O., Zo, H., Rho, J. J., \& Ciganek, A. P. (2012). Critical success factors for e-learning in developing countries: A comparative analysis between 
ICT experts and faculty. Computers \& Education, 58(2), 843-855. https://doi.org/10.1016/ j.compedu.2011.10.010

[6] Abu-Shanab, E., \& Al-Azzam, A. (2012). Trust Dimensions and the adoption of Egovernment in Jordan. International Journal of Information Communication Technologies and Human Development (IJICTHD), 4(1), 39-51. https://doi.org/10.4018/jicthd. 2012010103

[7] Alshwaier, A., Youssef, A., \& Emam, A. (2012). A new Trend for E-learning in KSA using educational clouds. Advanced Computing: An International Journal (ACIJ), 3(1), 8197.

[8] Madni. S, Abd Latiff. M, Coulibaly. Y ., \& Abdulhamid, S. M (2016) An Appraisal of Meta-Heuristic Resource Allocation Techniques for IaaS Cloud, Indian Journal of Science and Technology, Vol 9(4). https://doi.org/10.17485/ijst/2016/v9i4/80561

[9] Almudawi, N. A. (2016) 'Cloud Computing Privacy Concerns in Social Networks', International Journal of Computer (IJC), Vol 22, No 1, pp 29-36.

[10] Abdullahi M, Ngadi MA (2016) Symbiotic Organism Search optimization based task scheduling in cloud computing environment. Future Generation Computer Systems 56: 640-650 https://doi.org/10.1016/j.future.2015.08.006

[11] Madni, S. H. H., Latiff, M. S. A., Coulibaly, Y., \& Abdulhamid, S. M. (2016). Resource scheduling for infrastructure as a service (IaaS) in cloud computing: Challenges and opportunities. Journal of Network and Computer Applications, 68, 173-200. https://doi.org/10.1016/j.jnca.2016.04.016

[12] Kogyo. K (2016) Country Gender Profile: Hashemite Kingdom of Jordan Final Report, Japan International Cooperation Agency (JICA) Kokusai Kogyo Co., Ltd.

[13] Massadeh, S. A., \& Meslah, M. A. (2013). Cloud computing in higher education in Jordan. World of Computer Science and Information Technology Journal, 3, 38-43 .

[14] Al-Shboul, M., \& Alsmadi, I. (2010). Challenges of utilizing e-Learning systems in public universities in Jordan. International Journal of Emerging Technologies in Learning (iJET), 5(2). https://doi.org/10.3991/ijet.v5i2.1147

[15] Daly, E. J., Neugebauer, S., Chafouleas, S., \& Skinner, C. H. (2015).Interventions for reading problems: Designing and evaluating effective strategies. Guilford Publications.

[16] Dascalu, M. I., Bodea, C. N., Lytras, M., De Pablos, P. O., \& Burlacu, A. (2014). Improving e-learning communities through optimal composition of multidisciplinary learning groups. Computers in Human Behavior, 30, 362-371 https://doi.org/10.1016/j.chb. 2013.01.022

[17] Pierce, D. (2015). U.S. Patent No. 9,003,297. Washington, DC: U.S. Patent and Trademark Office.

[18] Vitolo, C., Elkhatib, Y., Reusser, D., Macleod, C. J., \& Buytaert, W. (2015). Web technologies for environmental Big Data. Environmental Modelling \& Software, 63, 185-198. https://doi.org/10.1016/j.envsoft.2014.10.007

[19] Wesley. J and Amutharaj. J (2015). Voice Over Internet Protocol in Distributed Environment Using MANETs, International Journal of Advanced Research Trends in Engineering and Technology (IJARTET) Vol. 2, Issue 3.

[20] Wang, Y. (2013). Distance language learning: Interactivity and fourth-generation Internetbased videoconferencing. CALICO journal, 21(2), 373-395.

[21] Erilli. N. A. and Alakus. K (2014). Non-Parametric Regression Estimation for Data with Equal Values, European Scientific Journal, vol. 10, no. 4, pp. 70-82.

[22] Wang, Q., Woo, H. L., Quek, C. L., Yang, Y., \& Liu, M. (2012). Using the Facebook group as a learning management system: An exploratory study.British Journal of Educational Technology, 43(3), 428-438. https://doi.org/10.1111/j.1467-8535.2011.01195.x 
[23] Kaye, A. R. (2012). Computer Supported Collaborative Learning. Computer Supported Collaborative Learning (Vol. 128, p. 125). Springer Science \& Business Media.

[24] Stav, J., Nielsen, K., Hansen-Nygard, G., \& Thorseth, T. (2010). Experiences Obtained with Integration of Student Response Systems for iPod Touch and iPhone into e-Learning Environments. Electronic Journal of e-Learning, 8(2), 179-190.

\section{Author}

Bader Methqal AlFawwaz is an Assistant Professor at the Department of Computer Information Systems, Prince Hussein Bin Abdullah College for Information Technology, Al Al-Bayt University, Jordan.

Article submitted 29 October 2016. Published as resubmitted by the author 13 December 2016. 